\title{
INSTANTÂNEOS DE UM MATRIMONIO MIXTECO: IRINEO E ROSALBA
}

\author{
Ana Luisa Fayet Sallas ${ }^{1}$
}

Na cidade do México em 2012, logo nos primeiros momentos de nossa pesquisa de campo sobre culturas juvenis no México, fomos convidados para acompanhar a montagem e realização de uma grande exposição de grafite, promovida por nossos principais interlocutores naquele momento, que eram os jovens donos da IlegalSquad loja sprays, camisetas, revistas e todo um conjunto de artefatos ligados a esta arte. A exposição/festival foi em Vale de Bravo, pequena cidade ao redor de uma represa a uns cento e cinquenta kms da CMX.

Nessa cidade conhecemos Ana Castilho e Wladimir Rhusso, um casal de jovens estudantes de Antropologia da Escola Nacional de Antropologia e História. De algumas conversas e uma carona de regresso à CMX, surgiu o convite para irmos no início de julho ao casamento de Ireneo e Rosalba, em Oaxaca, num pequeno povoado chamado Octopec - 173 habitantes quando lá estivemos. Ao notarem nossa ligação com a fotografia nos disseram que seriamos os "os padrinhos da fotografia". Indagamos se não era estranho convidar alguém que não pertencia ao grupo de convidados nos noivos e eles nos responderam rindo que não: "quanto mais convidados eles tiverem, mais é valorizada a união e a festa que promovem". Diante de tal argumento, e de alguns reencontros nosso pela cidade, deixamos de lado nossos receios e fomos juntos para Oaxaca nos primeiros dias de julho daquele ano. Éramos em 6 pessoas: além de nos quatro foi a mãe de Ana - Martha e uma outra colega antropóloga da universidade.

Chegamos em Santo Tomaz Octopec no dia 6 de julho, nas vésperas do casamento. Ficamos hospedados na casa dos parentes de Irineo, num galpão destinado a guardar mantimentos, instrumentos de trabalho, defensivos entre outras coisas. Tinha uma cama de casal que foi destinada aos gringos. Nossos amigos dormiram em seus colchões de acampamento no chão. Casa de paredes de madeira de tapumes, telhas de zinco, chão batido. Tudo muito simples. Os luxos estavam num pequeno quarto com televisão, rádio

\footnotetext{
${ }^{1}$ Universidade Federal do Paraná, Brasil. Email: analuisasallas@gmail.com ORCID id: https://orcid.org/0000-0001-9928-6771
} 
e uma geladeira. Toda a energia elétrica era obtida por geradores. A água era puxada de um pequeno rio que corria abaixo da propriedade. $\mathrm{O}$ banheiro era uma fossa que ficava há alguns metros distante da casa principal. Na propriedade da família haviam ainda três outras pequenas casas, ocupadas por diferentes integrantes da família. A maioria deles iam periodicamente aos EUA para trabalhar na colheita de tomate e abacaxi no Havaí. Eles integravam a chamada "comunidade em movimento" inserida no processo de migração transnacional ao EUA. O próprio Irineo já havia trabalhado nessas condições de trabalhador migrante temporário. Naquele momento, ele e Rosalba se dedicavam a venda de frutas e verduras próximo ao Mercado La Merced na CDMX. Eles haviam optado por estabelecer-se na Cidade do México também em função do nascimento do seu filho Hector. Então a cerimônia do casamento tinha um significado muito especial, porque finalmente eles tinham garantido as condições financeiras para realizar a festa, que se prolongaria por três dias e não mais as três semanas que antes a comunidade mixteca levava para a realização/celebração dos casamentos de seus integrantes. Hector já estava com dois anos. Algo que descobri posteriormente é que entre os mixtecos é reconhecida a coabitação do casal antes mesmo que o ritual do matrimonio seja realizado.

Para as fotografias nos organizamos de forma a cobrir todo o ritual do casamento, dos preparativos da véspera e do dia principal. Não fotografamos o último dia, que era um domingo e os festejos foram realizados pelo padrinho "da igreja" em sua casa e reservada aos familiares. Eu fotografei com minha máquina NIKON F3, utilizando filme fotográfico Ilford HP5 - B\&P e emprestei a máquina digital NIKON D90 para Wladimir fazer as fotos digitais. Eles ainda tinham duas outras máquinas digitais.

Quando chegamos na casa da família de Irineo e fomos apresentados para todos e muito bem acolhidos. Logo nos envolvemos em fazer as lembranças do casamento e encher os balões - junto as que crianças - que enfeitariam o grande pátio coberto onde seria realizada a festa (foto 1 ). 


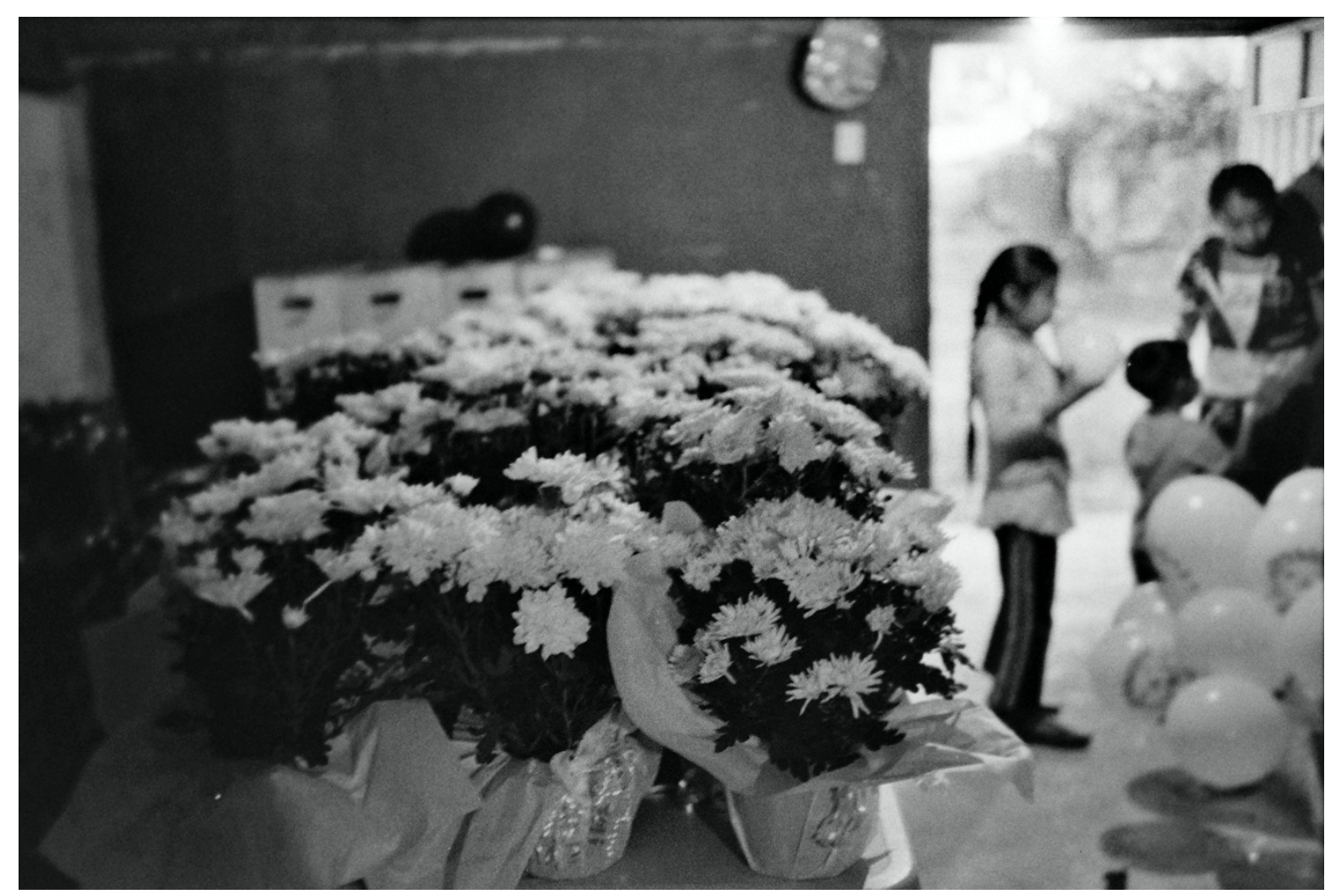

Foto 1

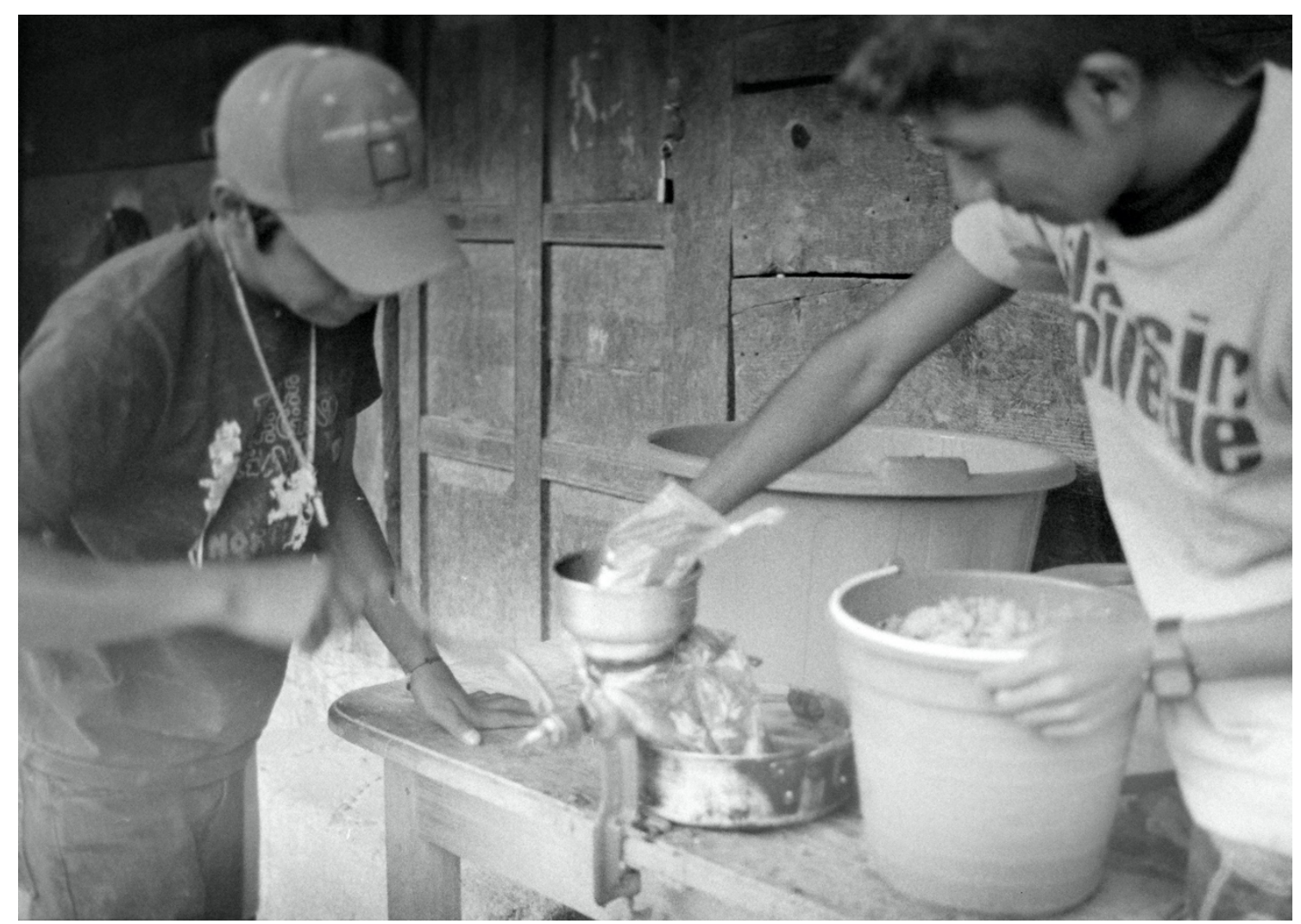

Foto 2 
No inicio ele era cozido numa grande panela no fogão improvisado fora da casa. Os irmãos e a abuelita de Irineo começaram a preparar o mole, triturando todos os seus ingredientes (foto 2). A preparação seguiu noite e madrugada adiante (foto 3). Pela manhã todo o rico alimento estava sendo adensado num fogo de chão - dentro de uma panela de barro de uns $90 \mathrm{~cm}$ de altura por 1,50 cm de largura. Ao redor dessa panela estavam as mulheres da família mexendo de quando em quando a grande panela. Ao lado da casa, algumas mulheres estavam limpando os frangos que seriam preparados com o mole. Todos nós despertamos bem cedo. Eram 5:30 horas e o dia estava vindo 


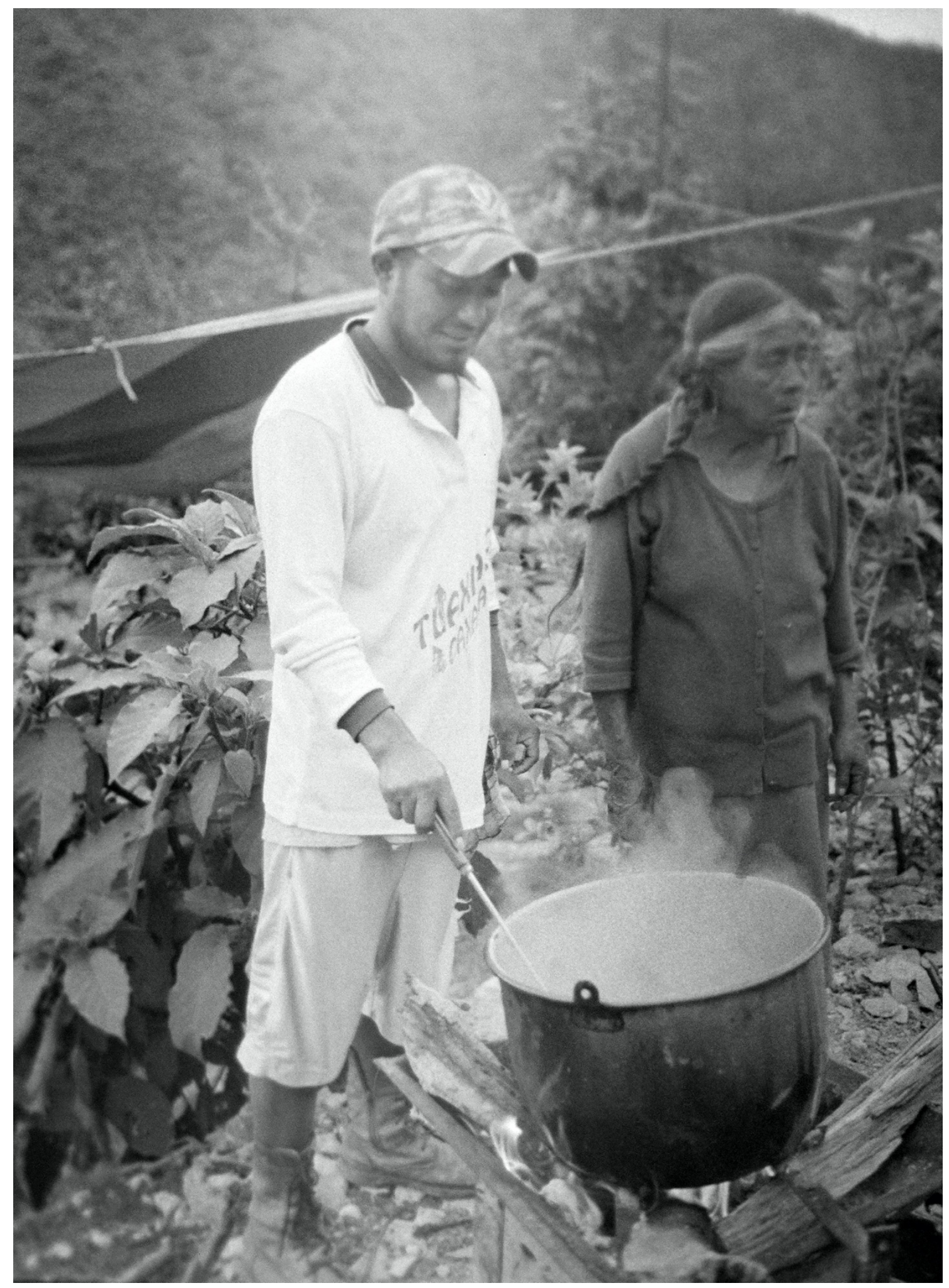

Foto 3 


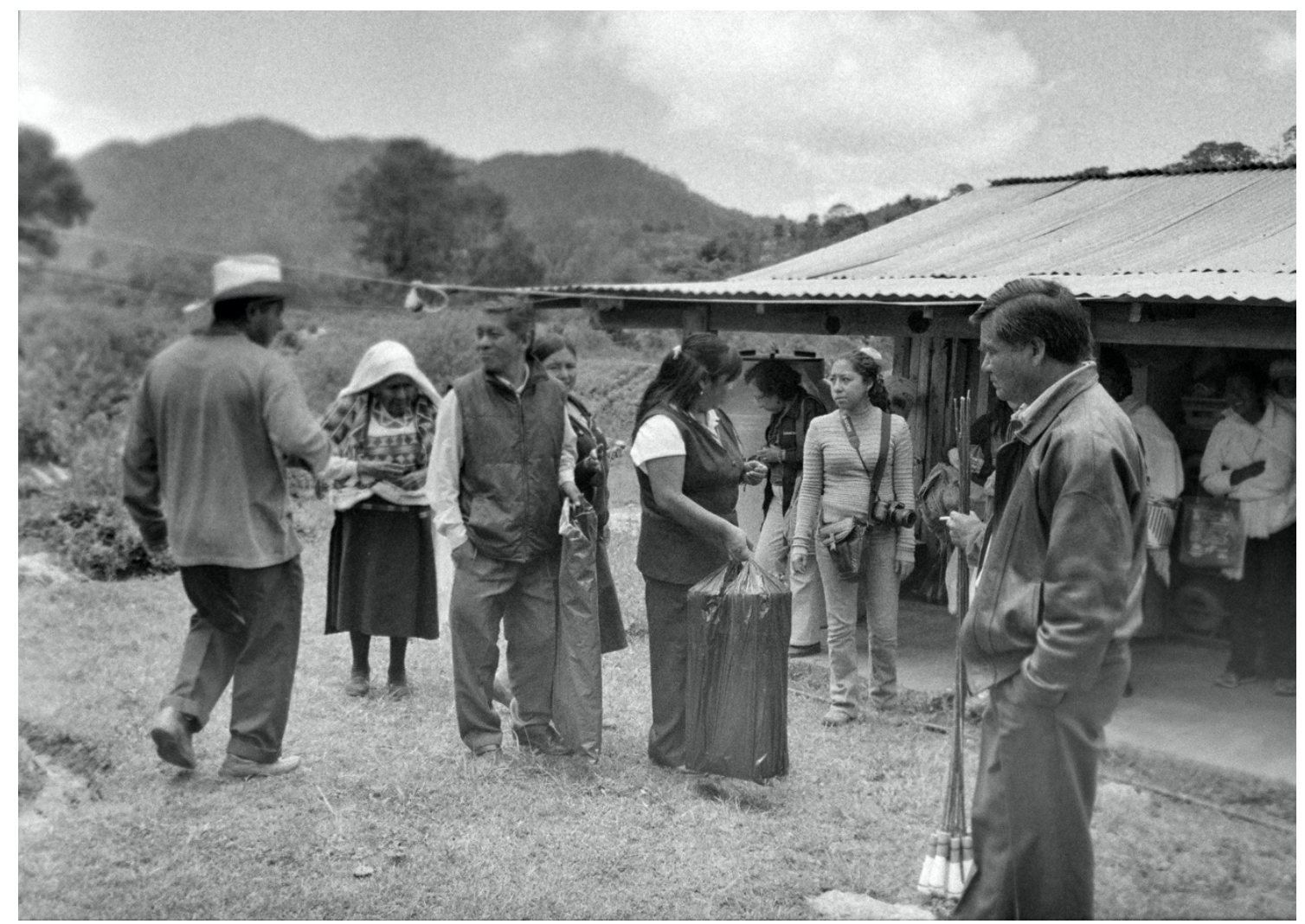

Foto 4

Aguardamos todos os familiares, padrinhos e madrinhas, convidados para irmos juntos para a casa da família de Rosalba. Sua família morava há uns $10 \mathrm{~km}$ montanha acima. Quando chegamos ainda esperamos a chegada do Embaixador para entrar na casa onde foi realizada a cerimônia (foto 4). Observa-se que as mulheres mixtecas mais velhas utilizam a tradicional manta branca e preta sob as cabeças. Os homens utilizam um chapéu de palma.

O embaixador é uma figura central no ritual do matrimonio mixteco, pois ele é em grande medida o depositário da tradição oral da comunidade, conhecendo em profundidade as suas origens e linhagens familiares que a constituem. Ao longo do ritual no interior da casa em sua fala - que não entendíamos muito bem - destacava-se a palavra compromisso (Foto 5). O embaixador é o guardião da memória e tradição da comunidade local. 


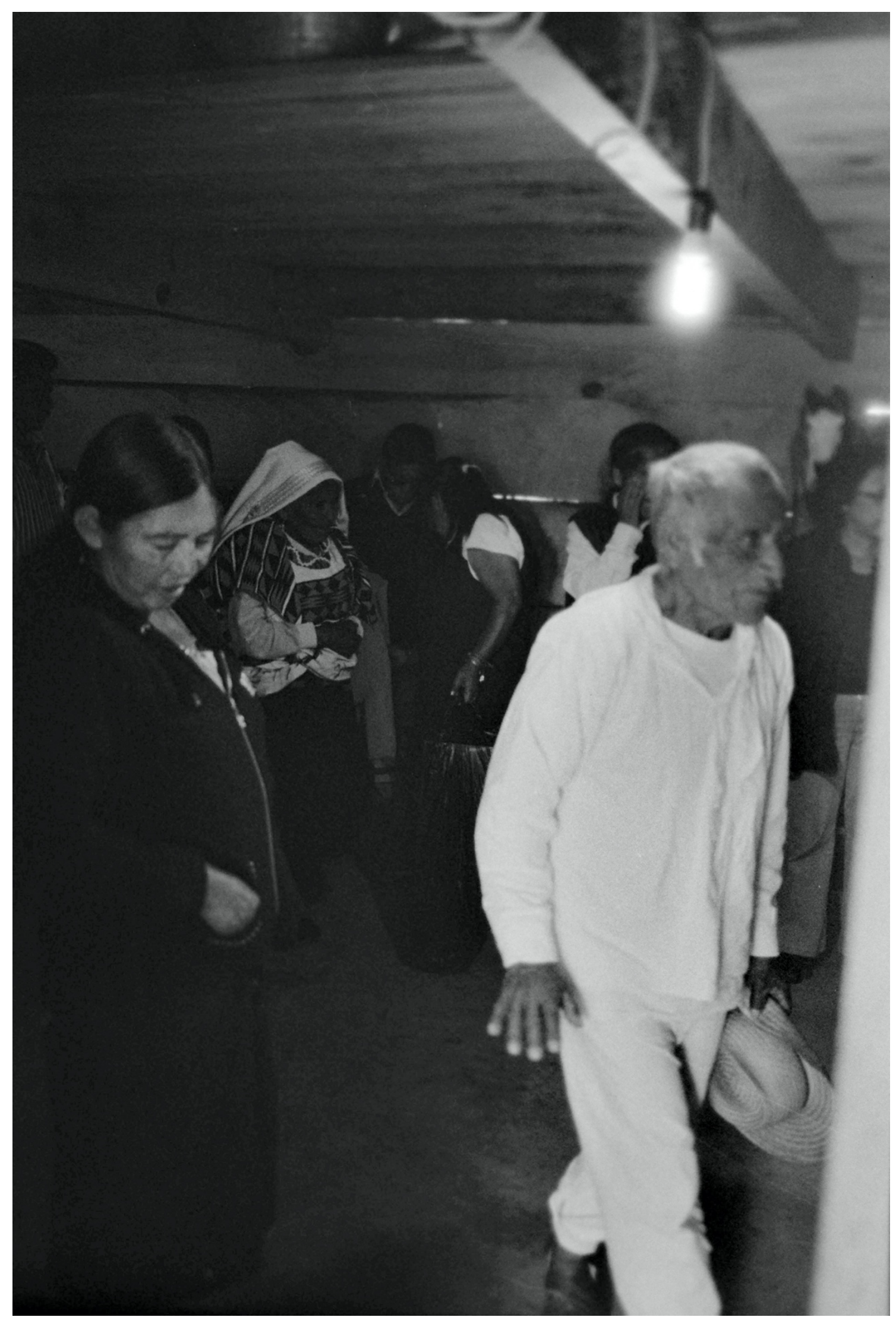

Foto 5 


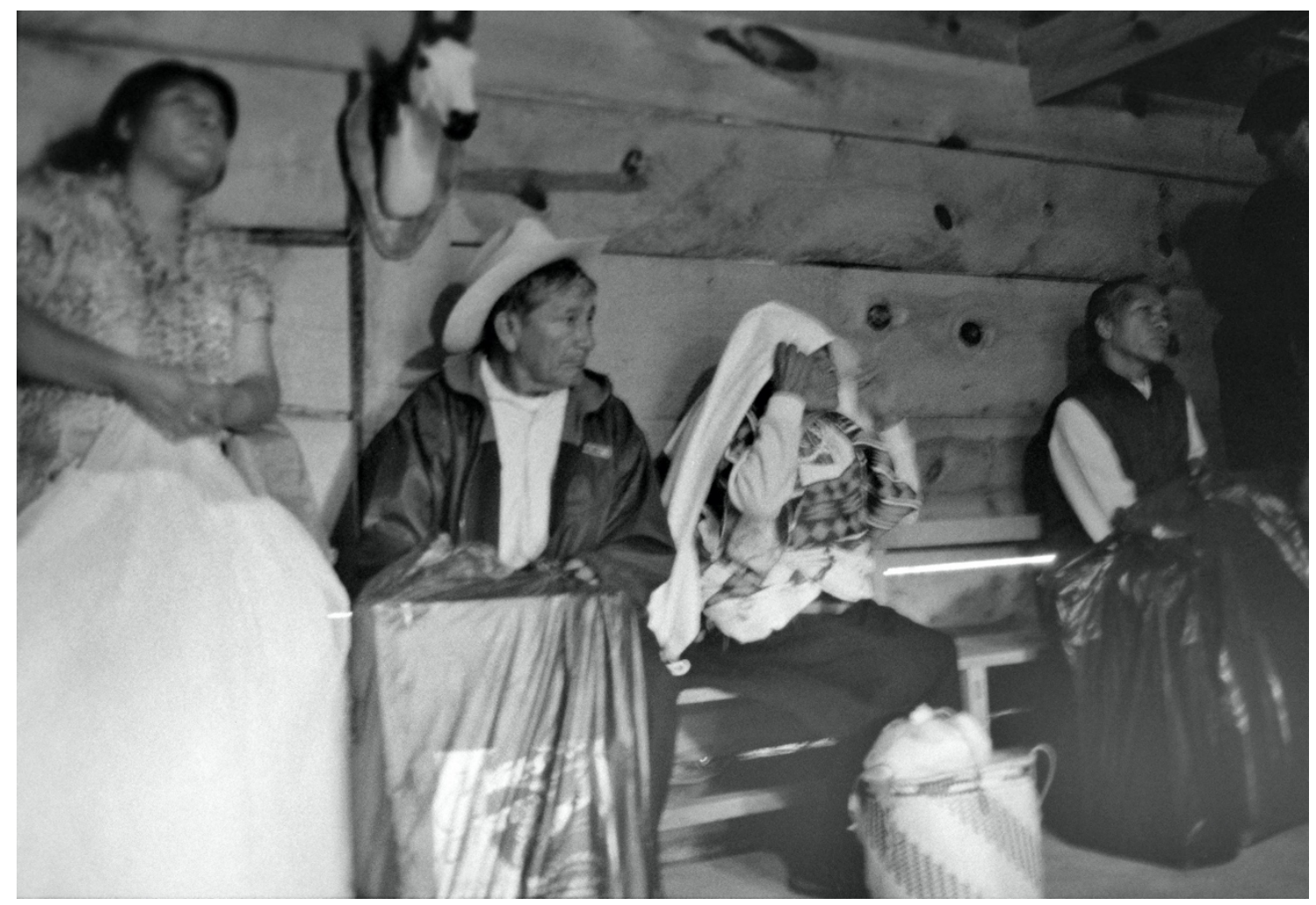

Foto 6

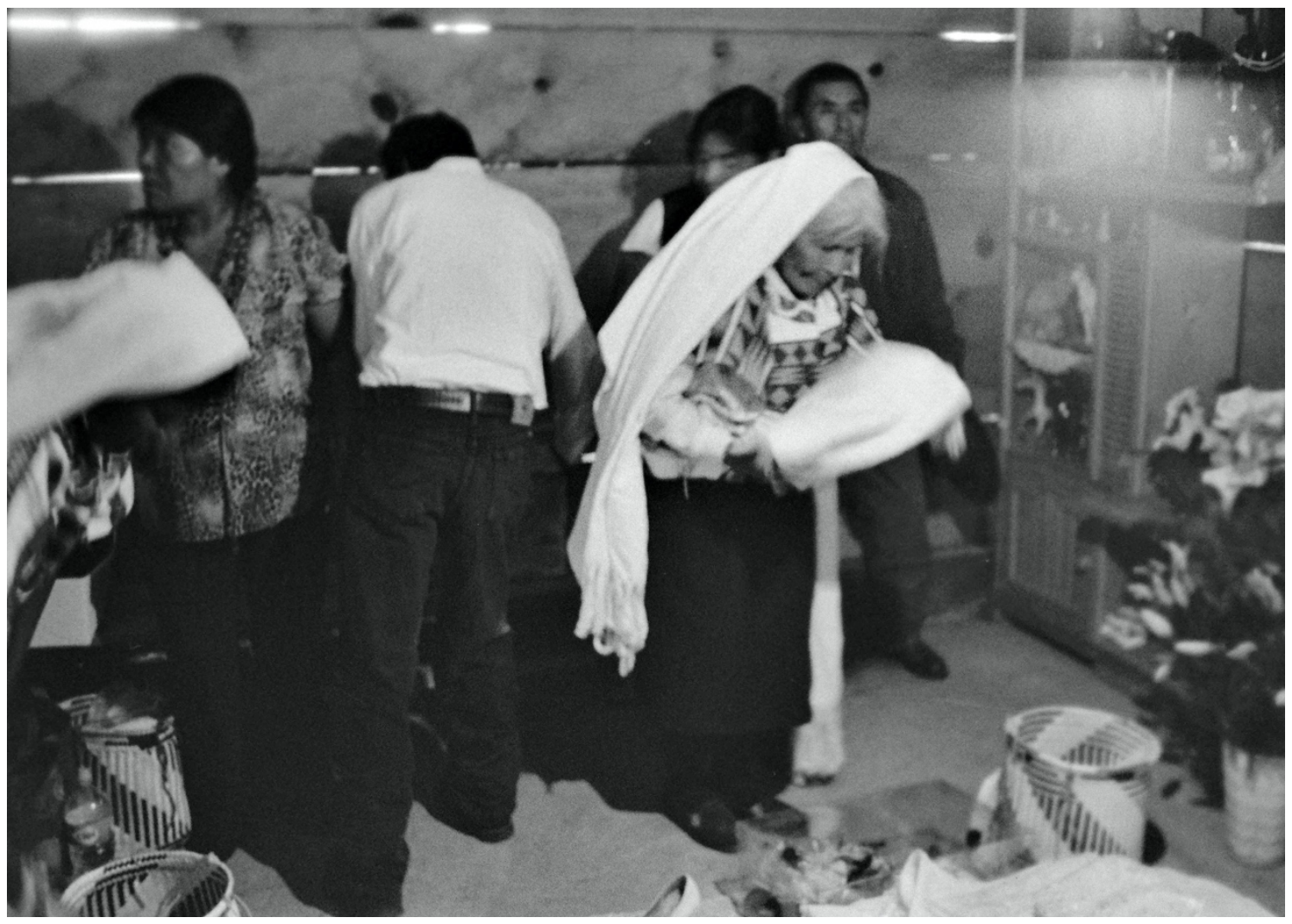

Foto 7 


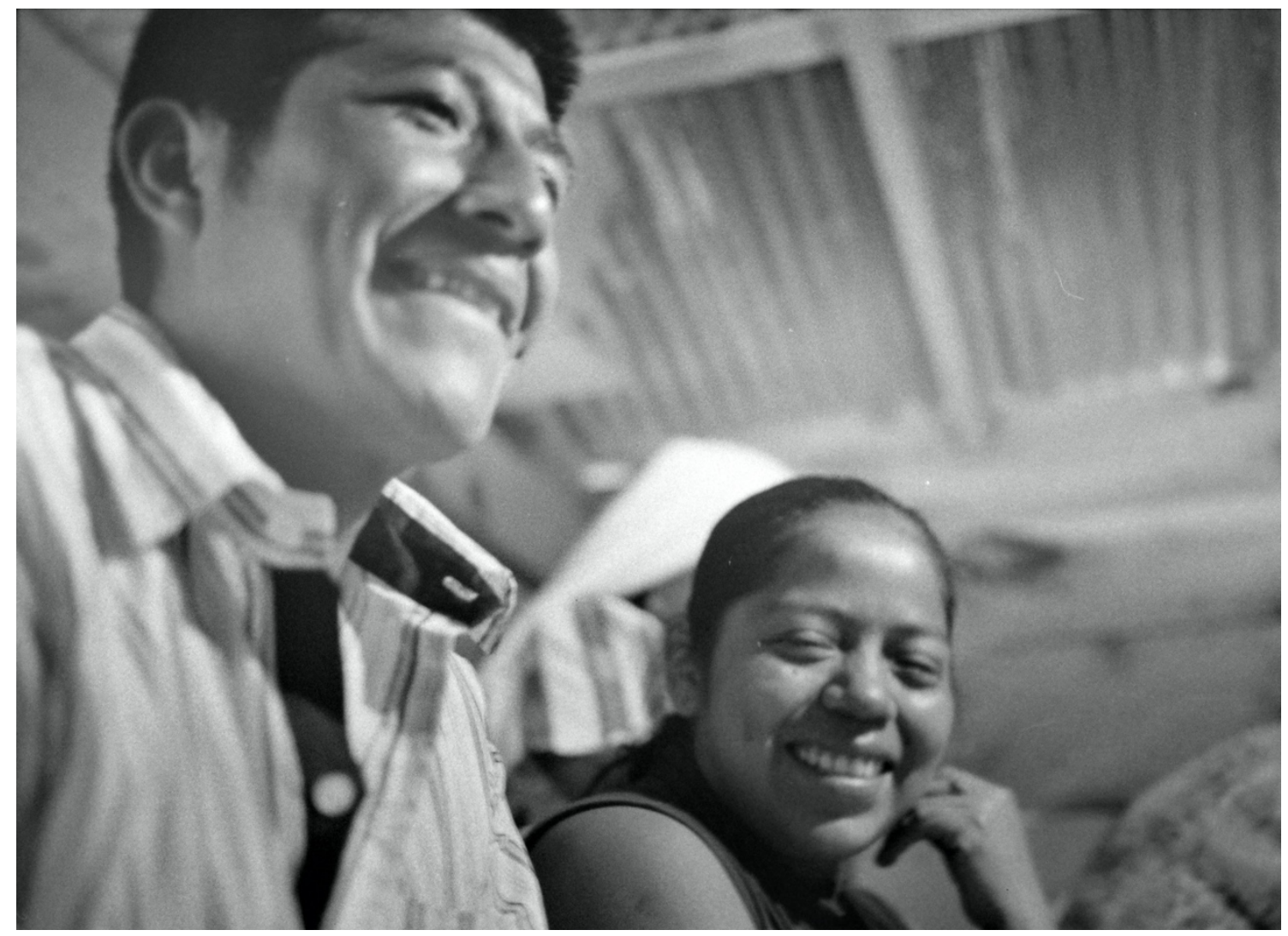

Foto 8

As madrinhas e padrinhos presenteiam os noivos com as roupas do casamento. Note-se que nas fotos 6 e 7 eles aguardam o término da fala do Embaixador para realizarem as suas oferendas não só das roupas completas para os noivos e seu filho pequeno, mas também com vários itens do enxoval, passando por cestas com alimentos como tacos e tlaludas.

Após a entrega destes presentes aos noivos (foto 8) tem inicio uma outra parte do ritual, que é a entrega dos colares cerimoniais que marcam a aliança dos noivos e reforçam os vínculos da linhagem. Quem entrega aos noivos esses colares é um mestre cerimonial "civil" que reforça também a ideia de compromisso ali assumido (foto 9 e 10). É notável a mescla de elementos aqui presentes, que se traduzem pela junção desses colares cerimoniais com os terços da igreja católica. 


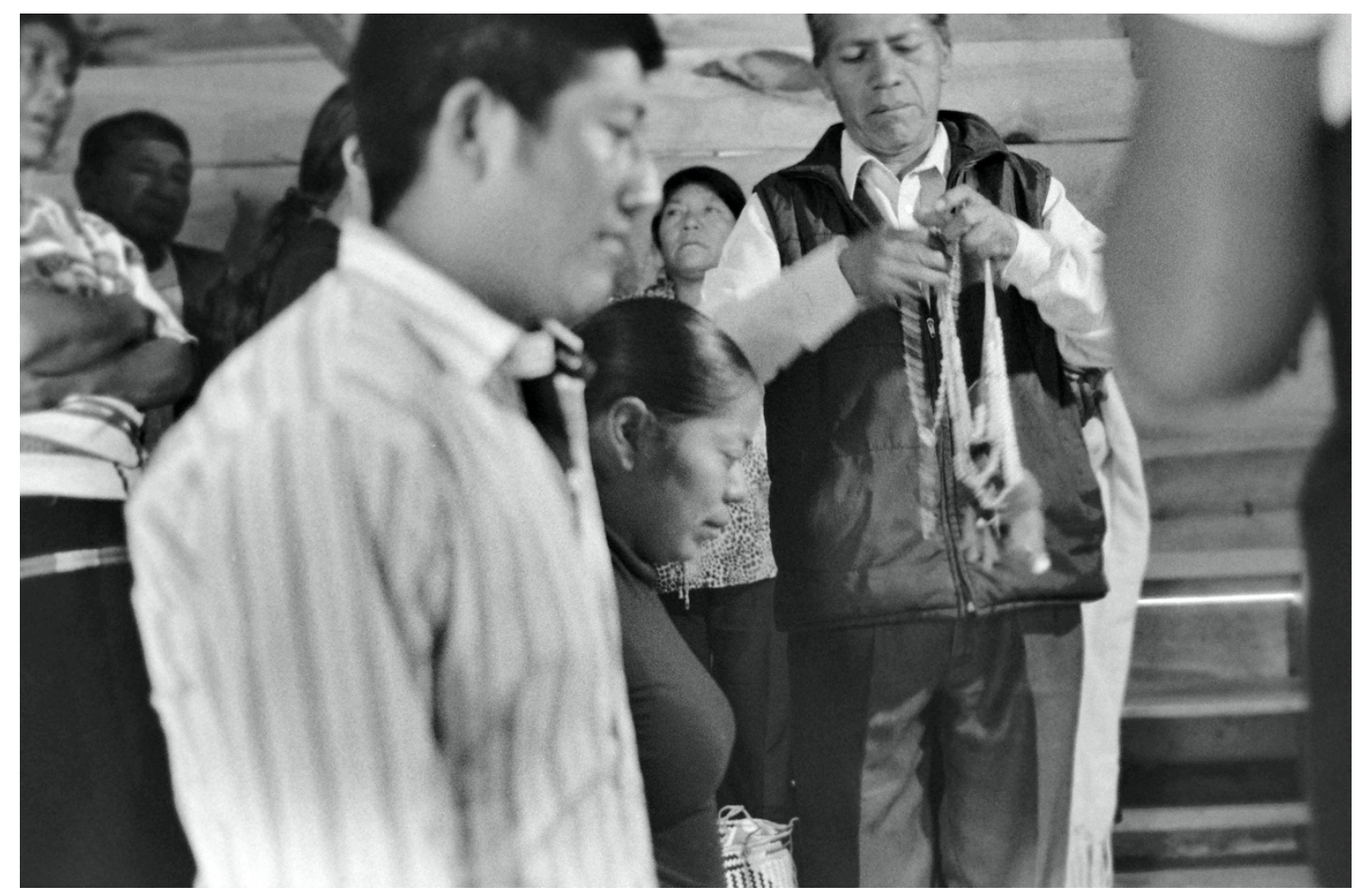

Foto 9

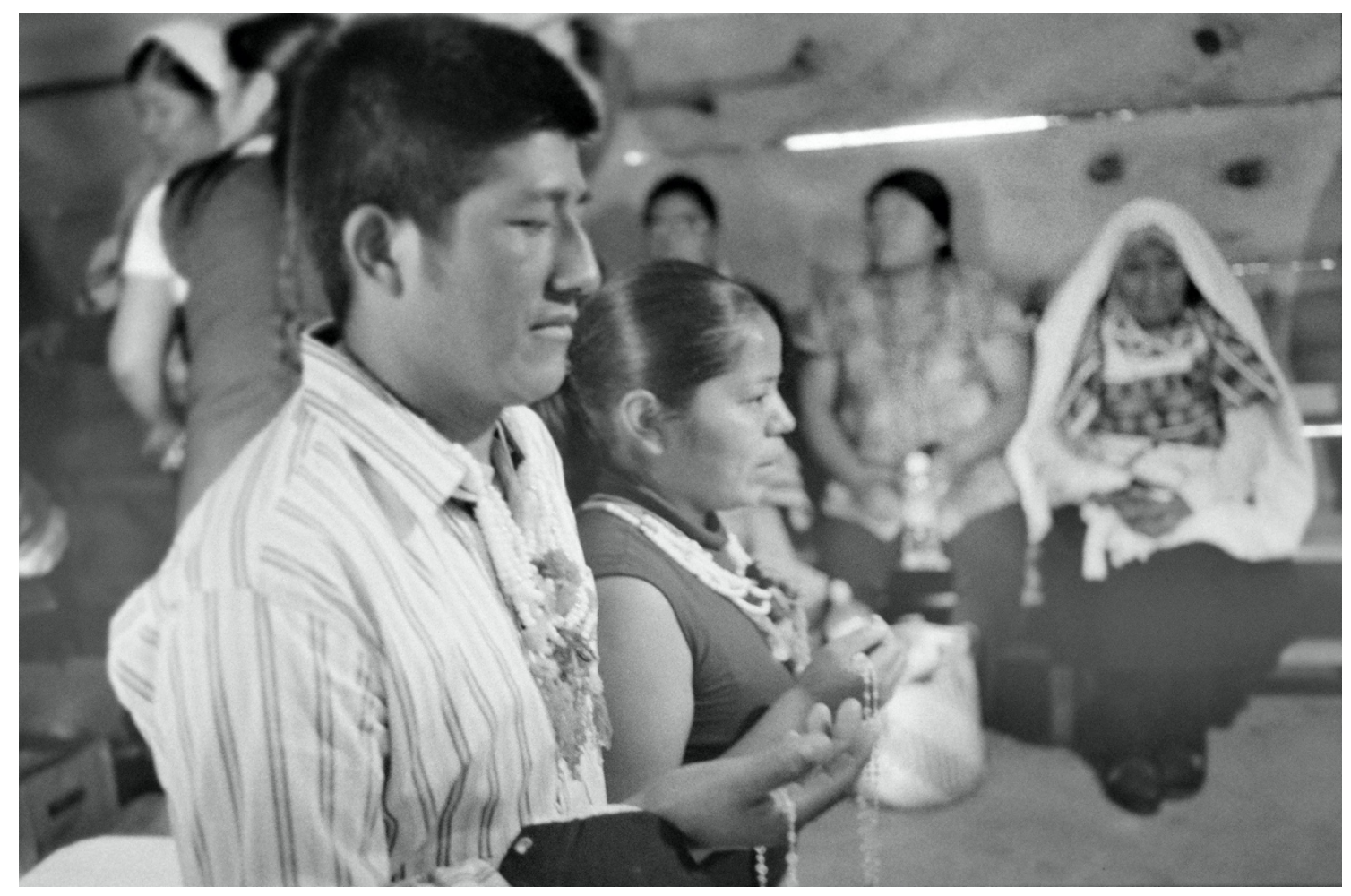

Foto 10 


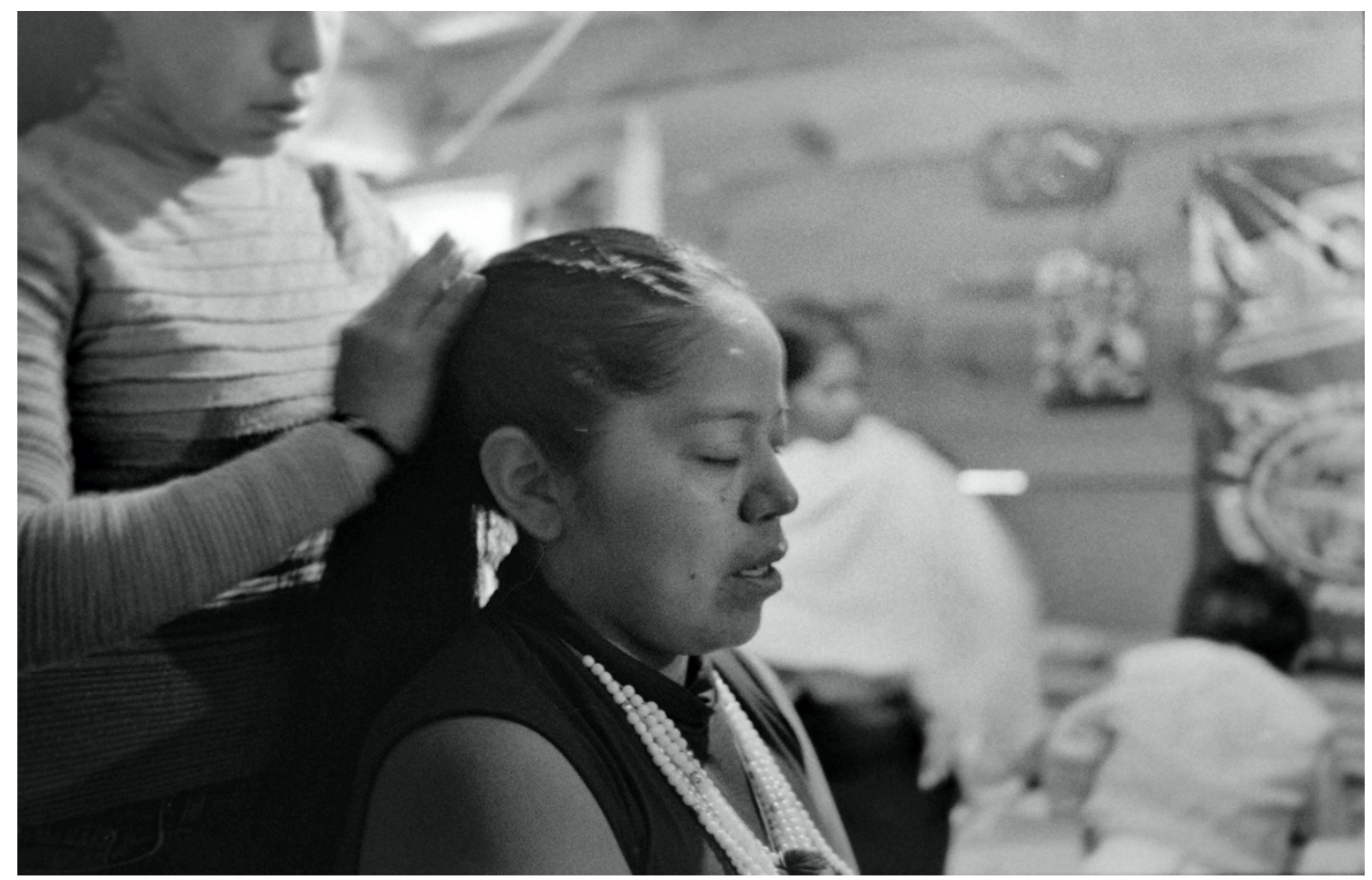

Foto 11

Momento de forte carga emocional e afetiva dos participantes, a cerimônia é encerrada para que eles se preparem para já com os trajes estabelecidos, irem para a igreja para a cerimônia religiosa. Na foto 11 , Rosalba é arrumada para a continuidade da celebração. Abaixo, vemos Ireneo (foto 12) já paramentado para o casamento religioso, bem como seu filho (Foto 13)

Nas fotos 14 e 15 vemos Rosalba já pronta para o seguimento do ritual. Partimos todos novamente para a sede do povoado, em direção a igreja local. 


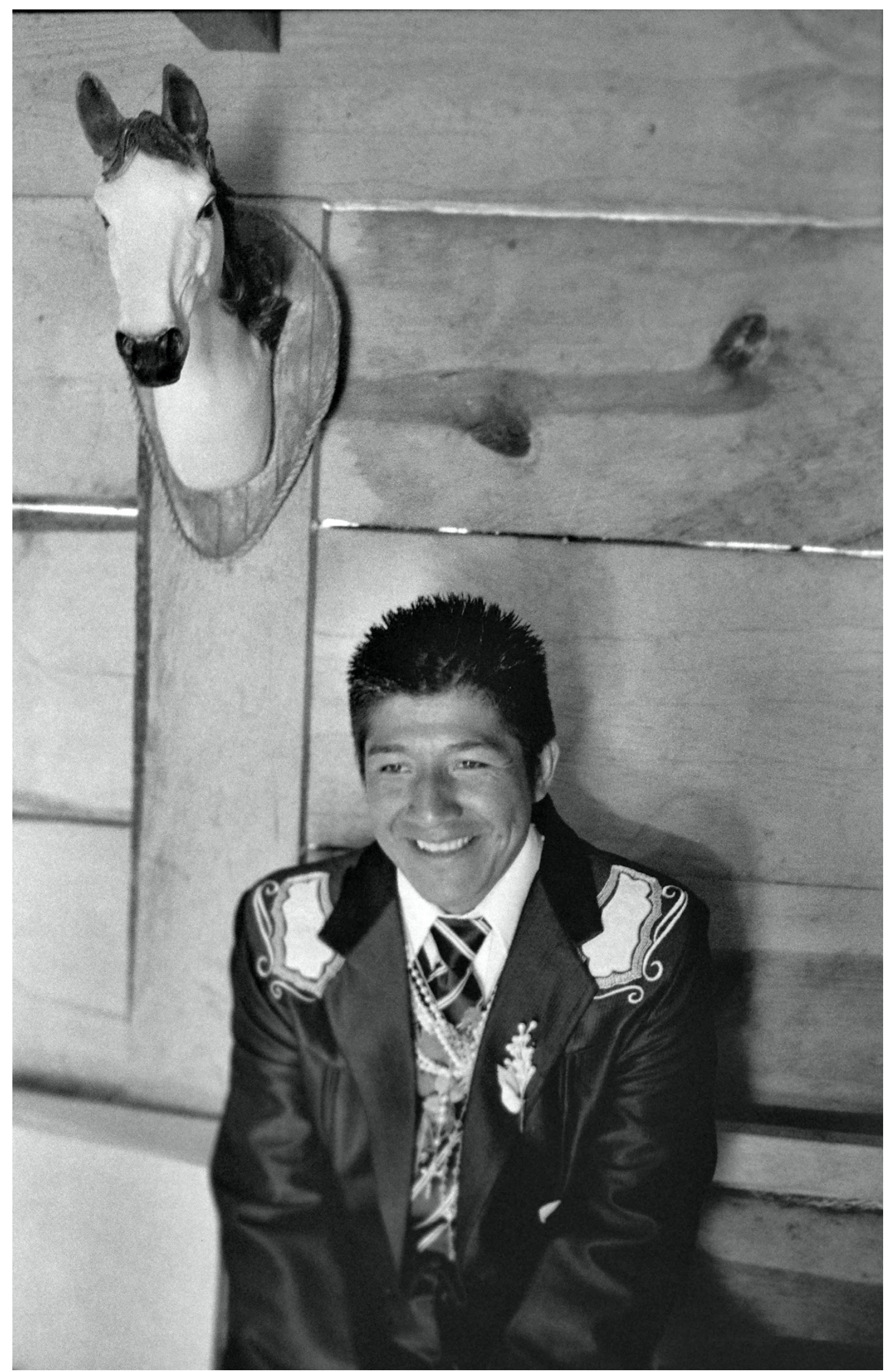

Foto 12 


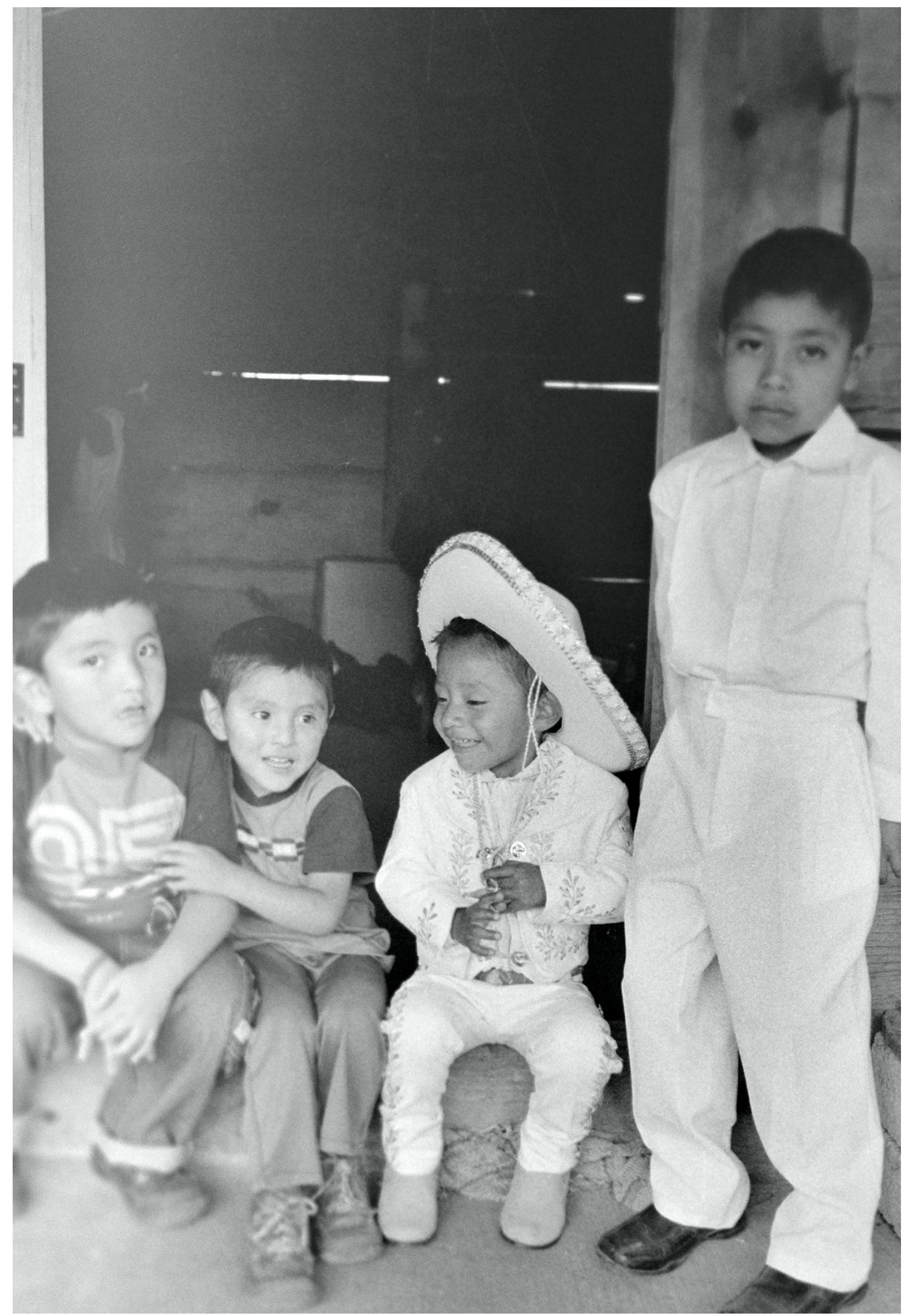

Foto 13 


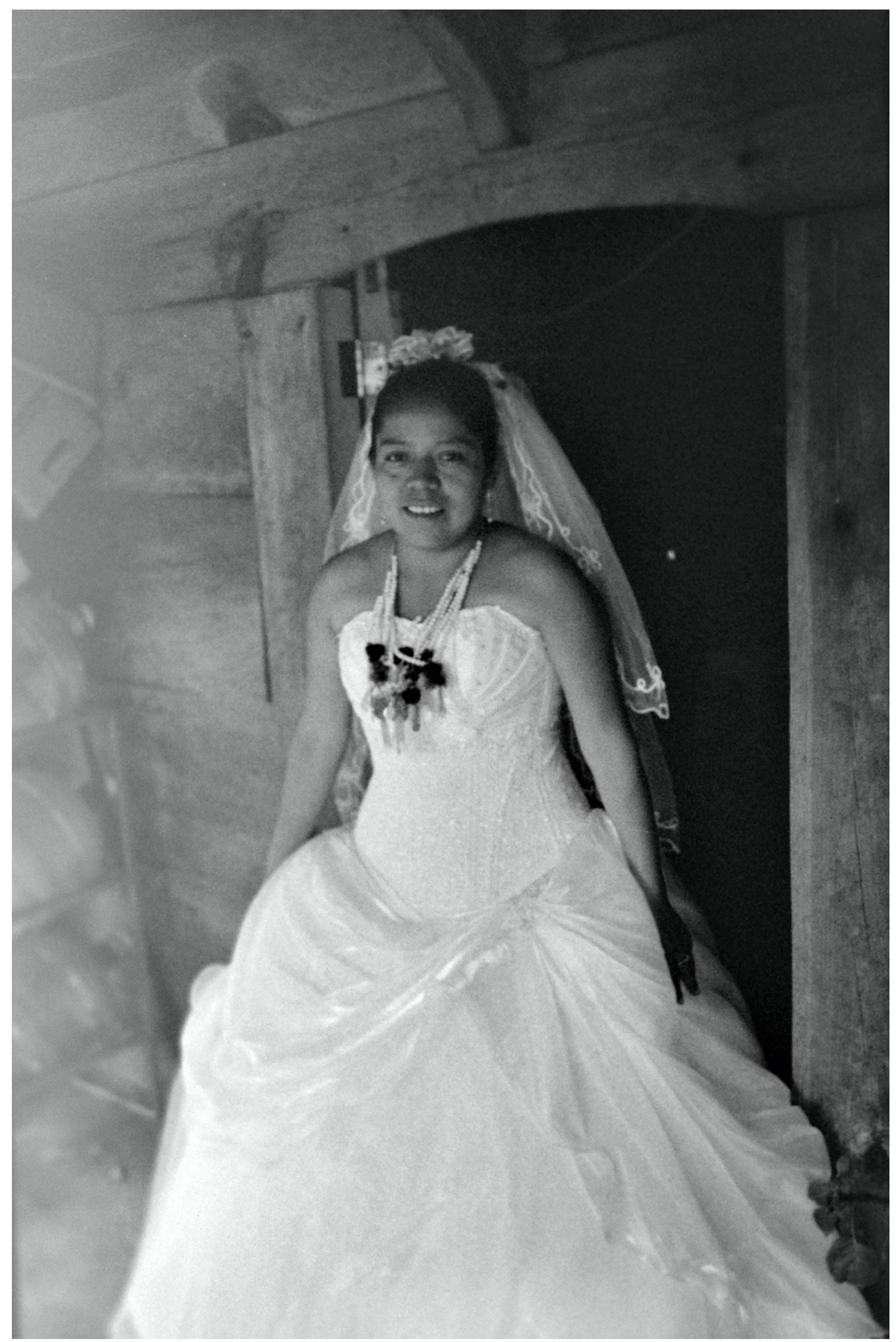

Foto 14 


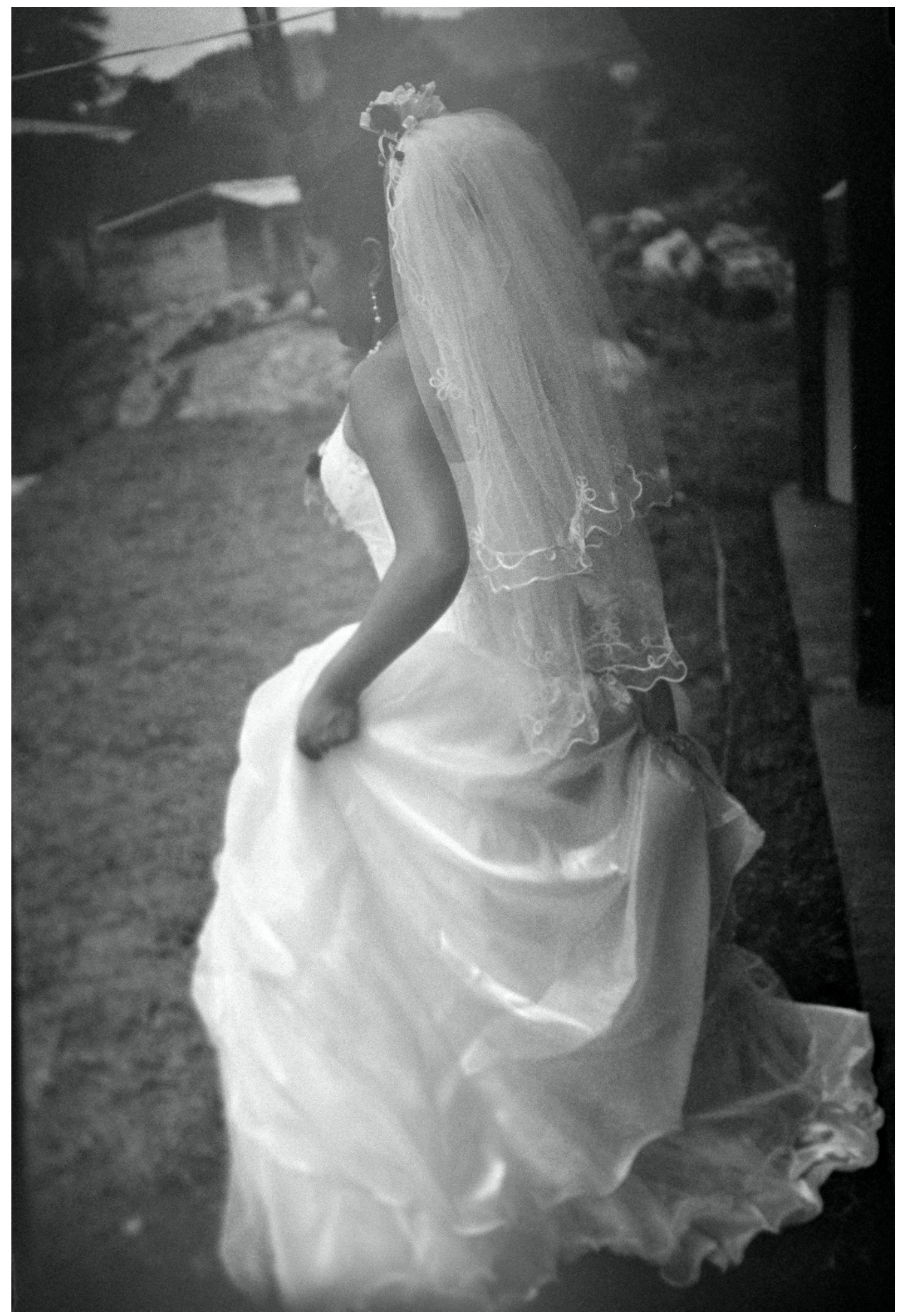

Foto 15 


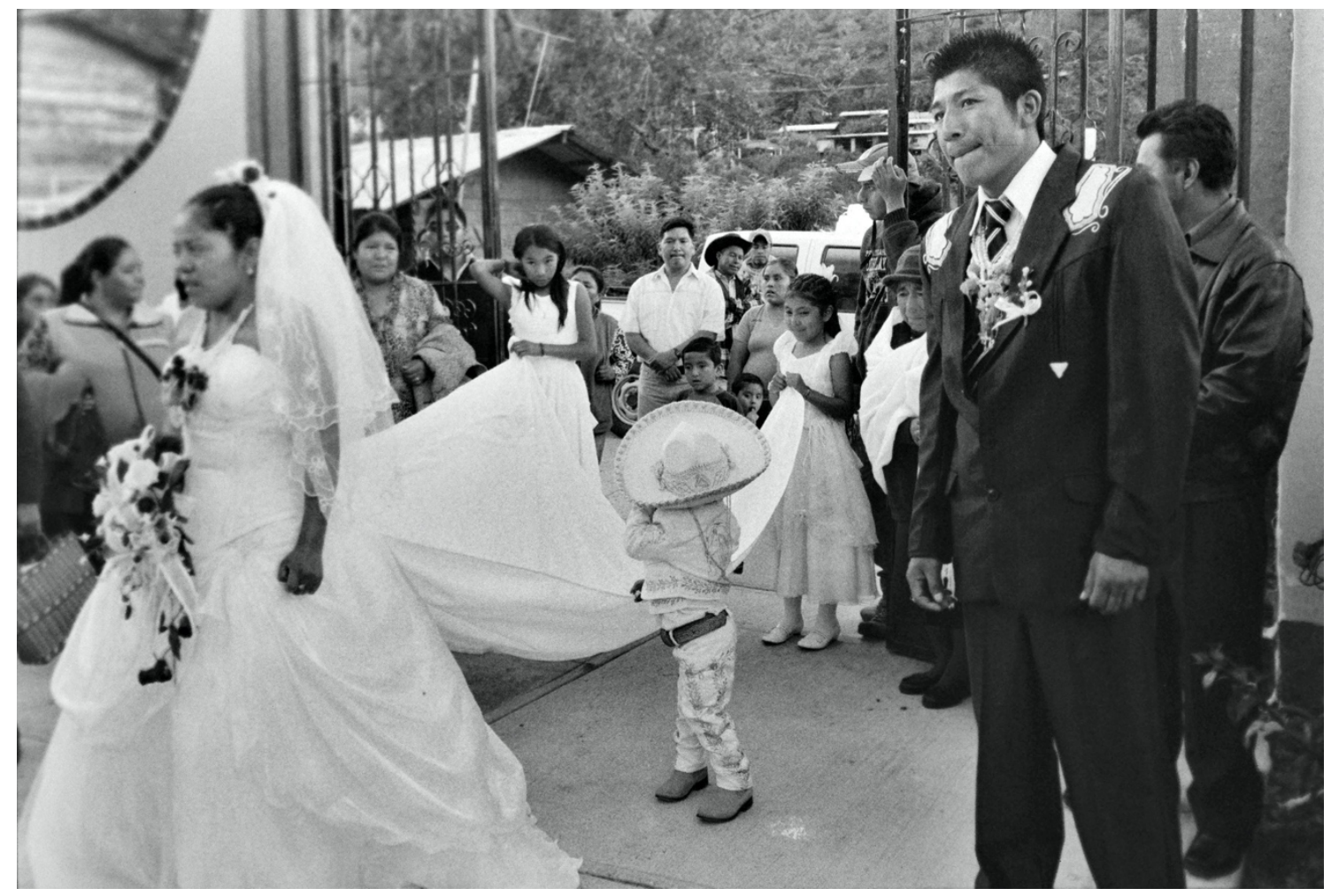

Foto 16

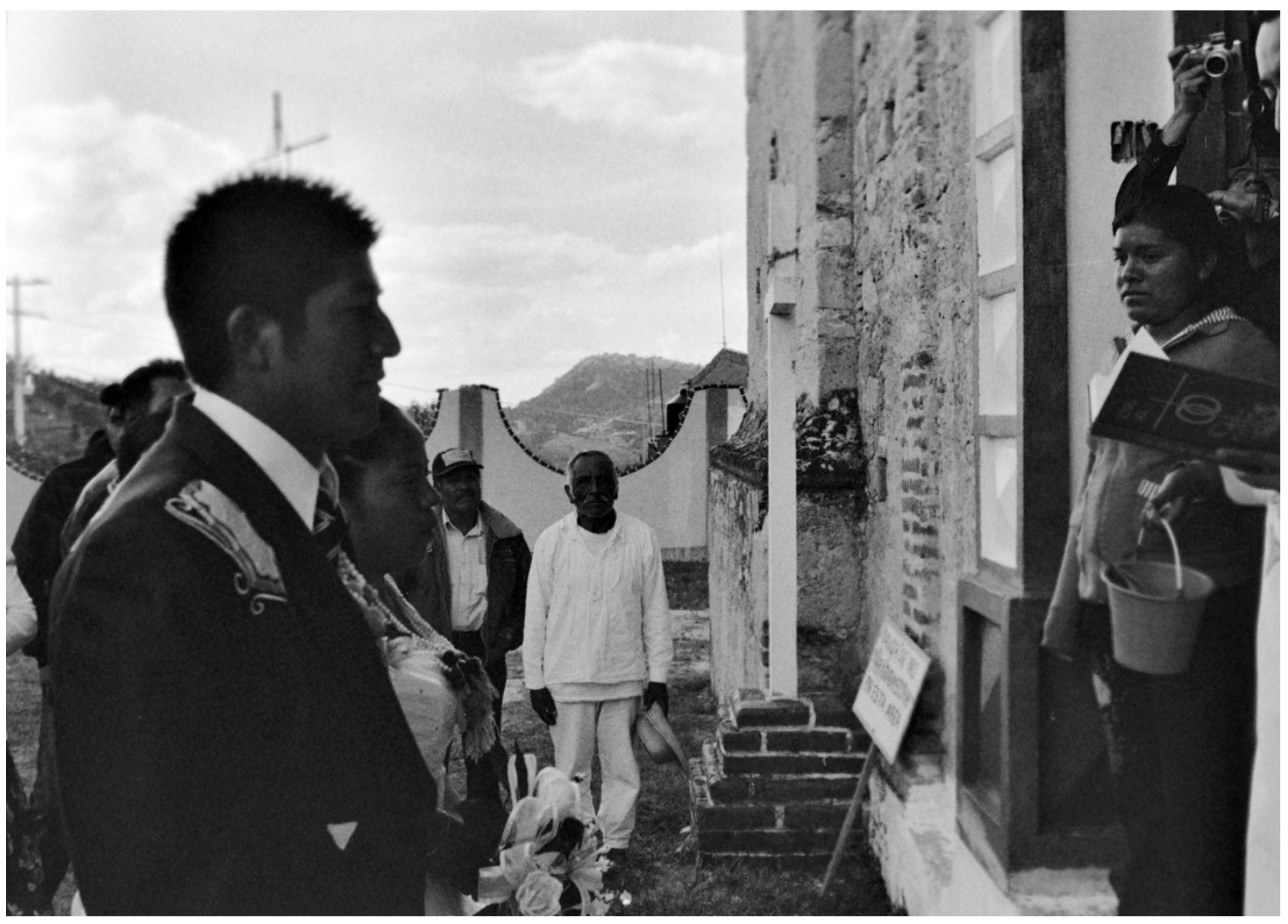

Foto 17 
Momento importante da chegada dos noivos na porta da igreja (foto 16 e 17) onde são recebidos pelo padre com uma fala inicial de boas vindas e de que o matrimônio fecundo. Mediando esse momento, vemos a figura do embaixador.

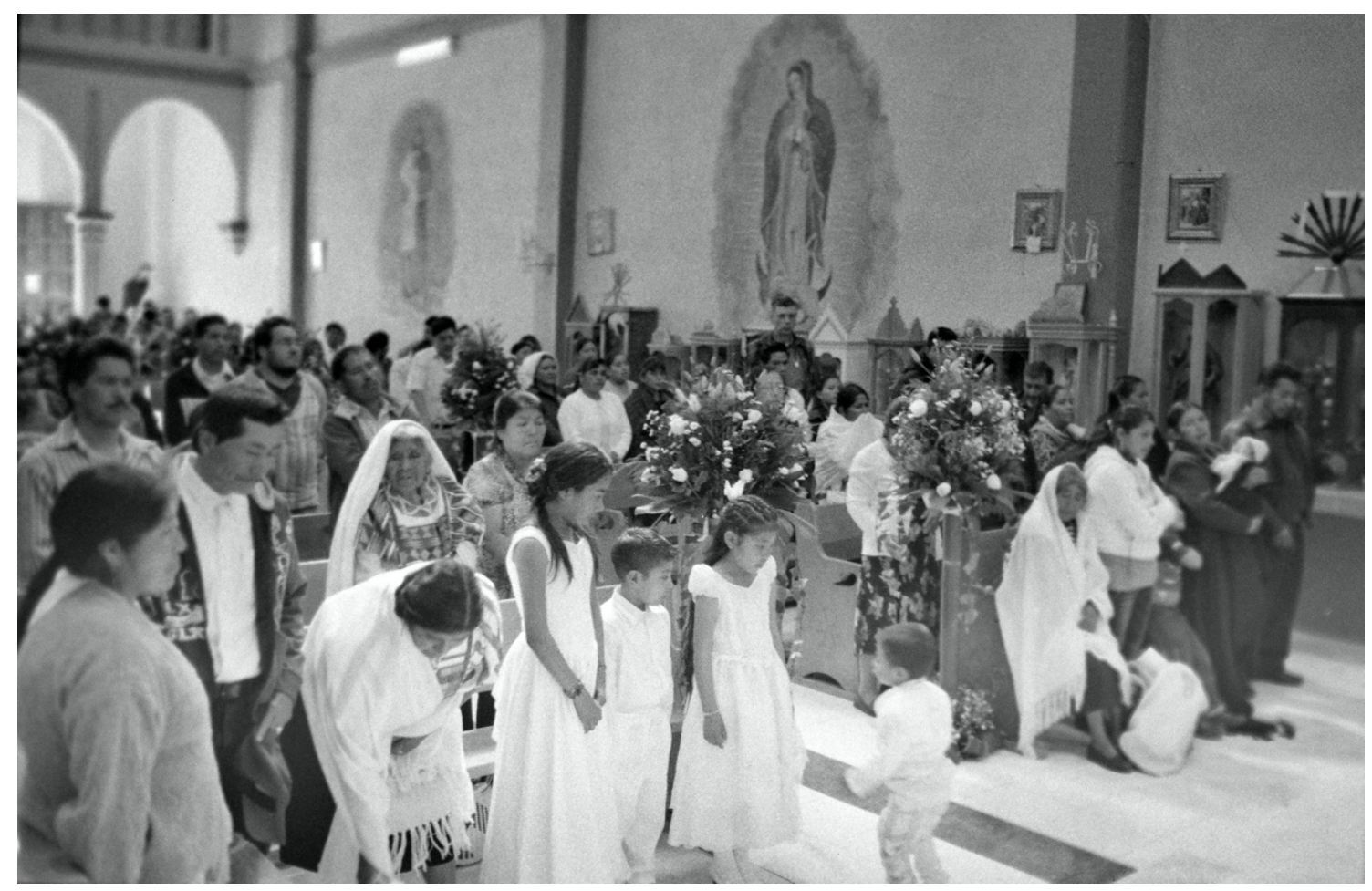

Foto 18

A chegada dos noivos na igreja é aguardada com alegria por todos os convidados, padrinhos e madrinhas, que enchem completamente o local. A troca de alianças é realizada (foto 18 e 19) e dá-se um momento especial do ritual em que os noivos são enlaçados por uma fita branca amarrada pela mãe de Rosalba (Foto 20). 


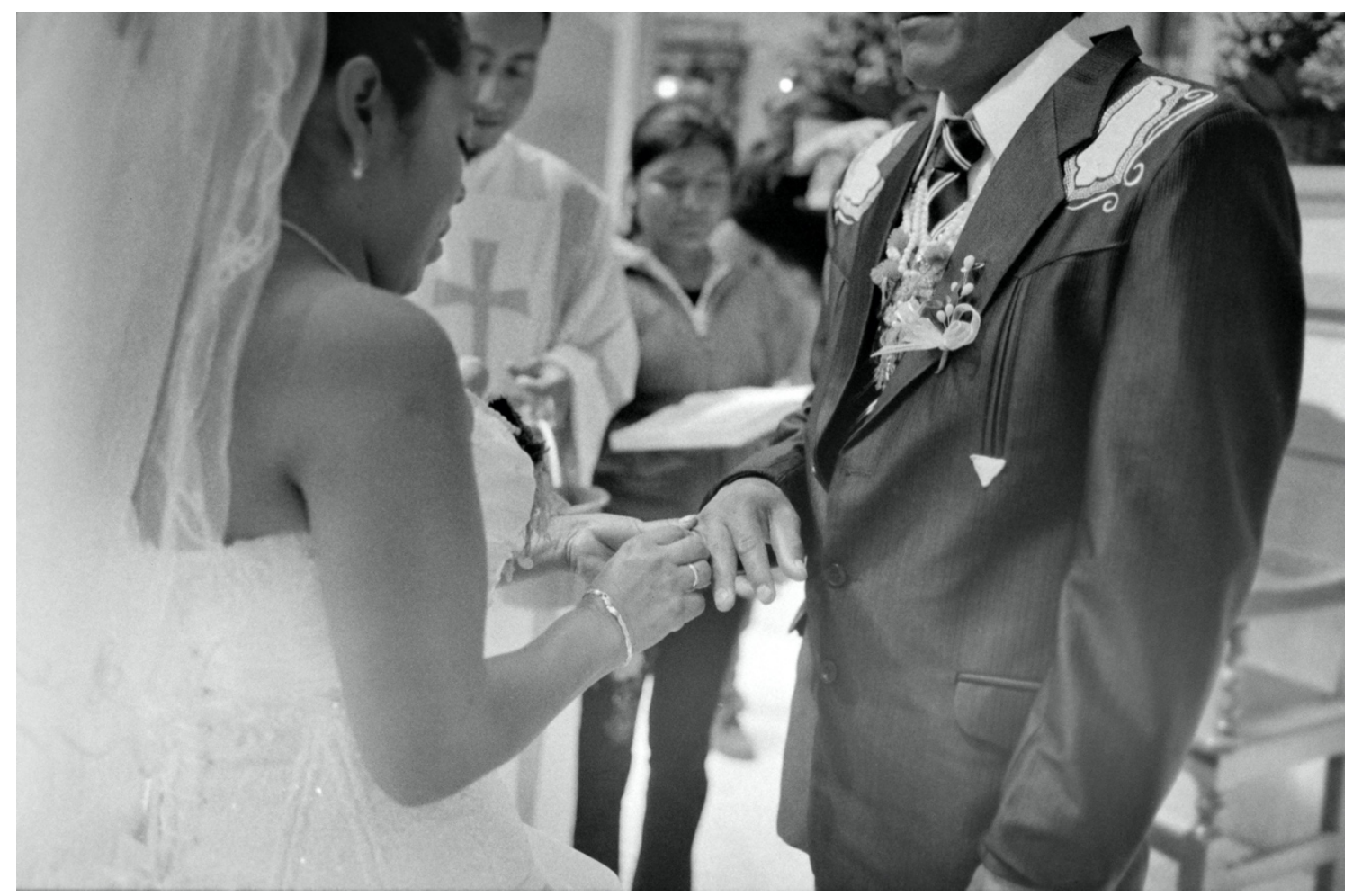

Foto 19

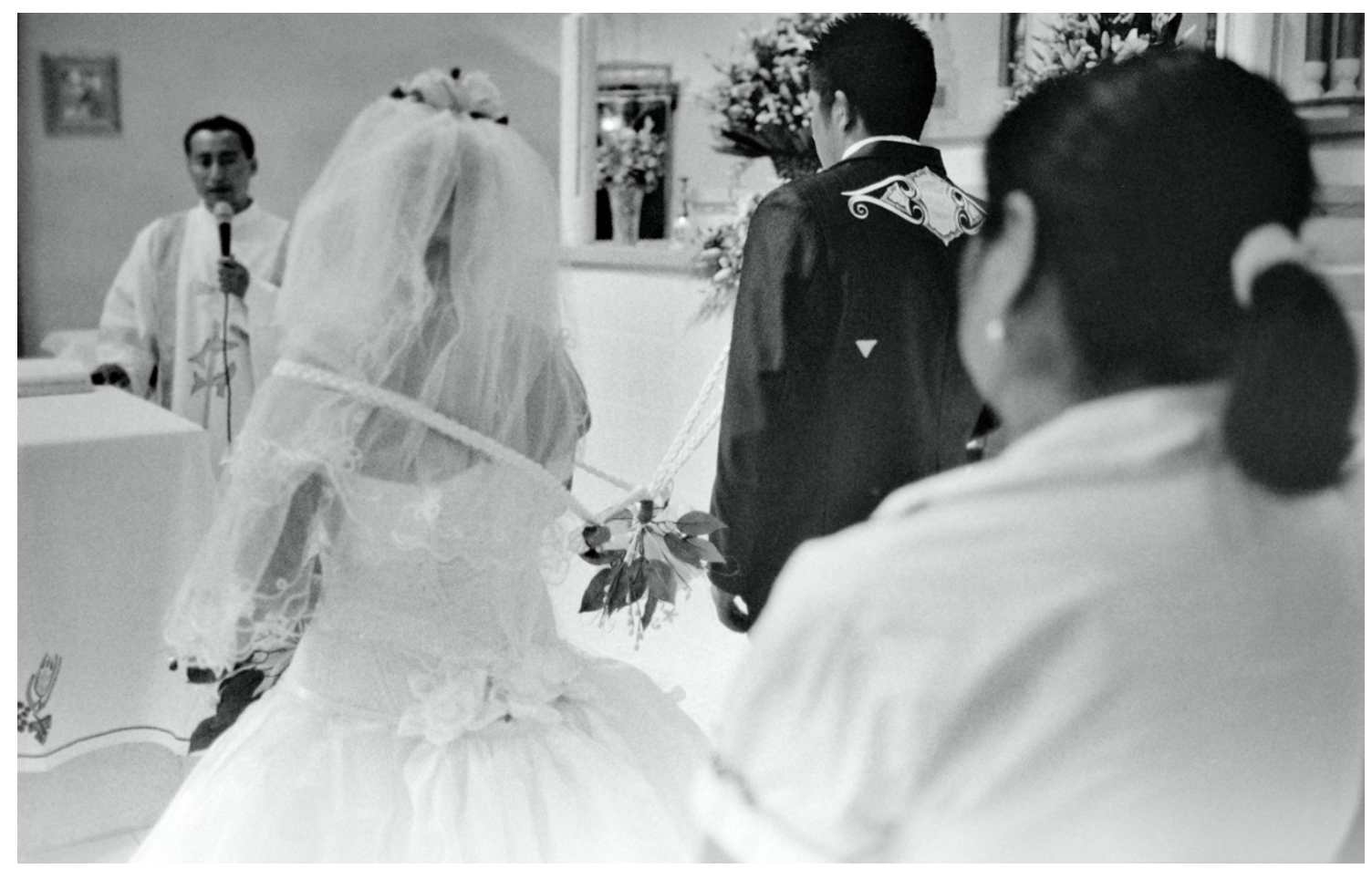

Foto 20 
Quando é finalizada a cerimônia, os noivos saem da igreja rumo à casa da família de Irieno. Esse percurso é feito a pé pelos noivos e convidados. Enquanto isso, as madrinhas do casamento vão de carro para aguardar a chegada do casal. Trata-se de um momento muito importante, porque novamente o saber local é acionado para brindar os noivos com a benção de plantas purificadoras (foto 21 e 22). 


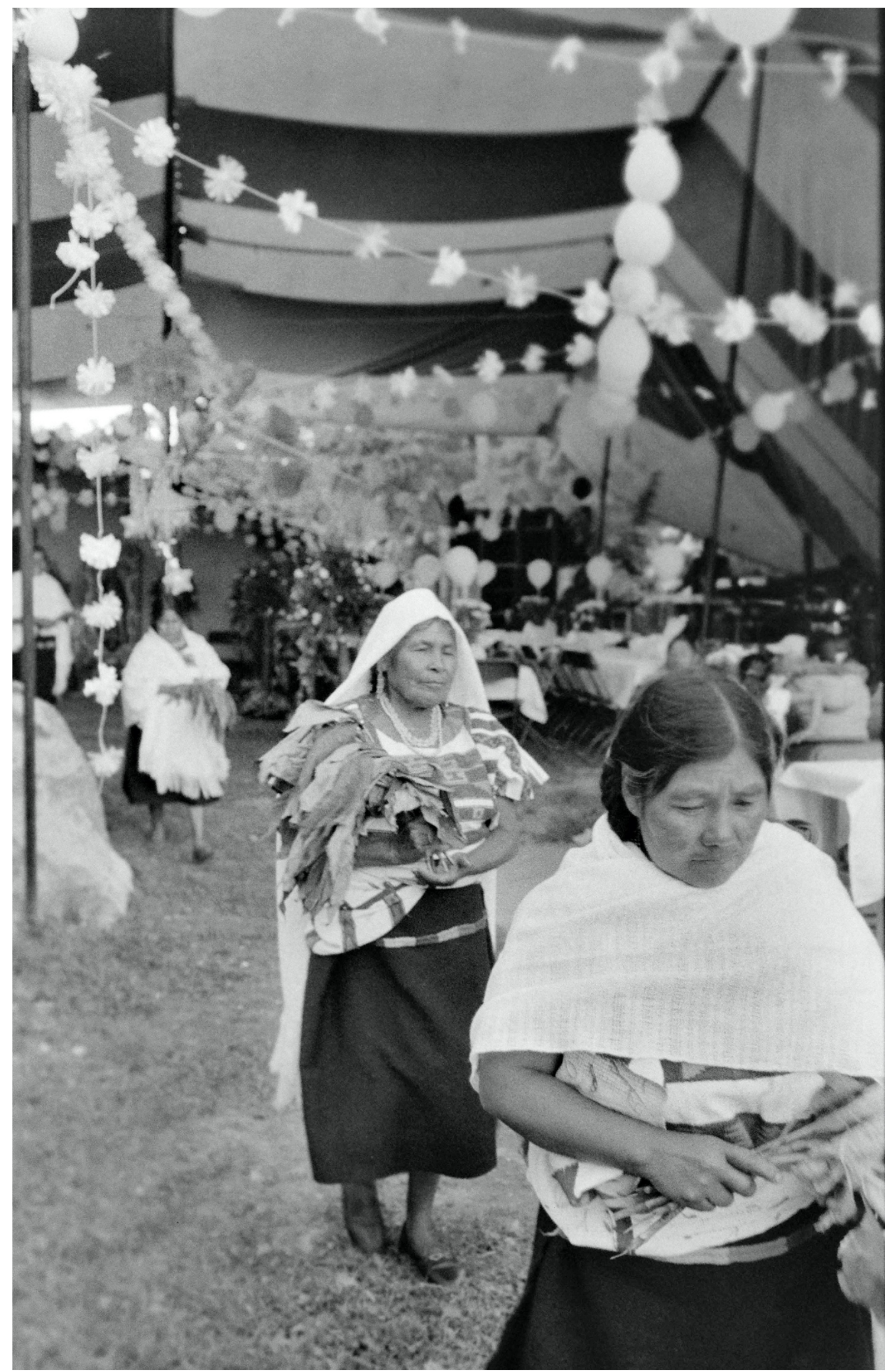

Foto 21 


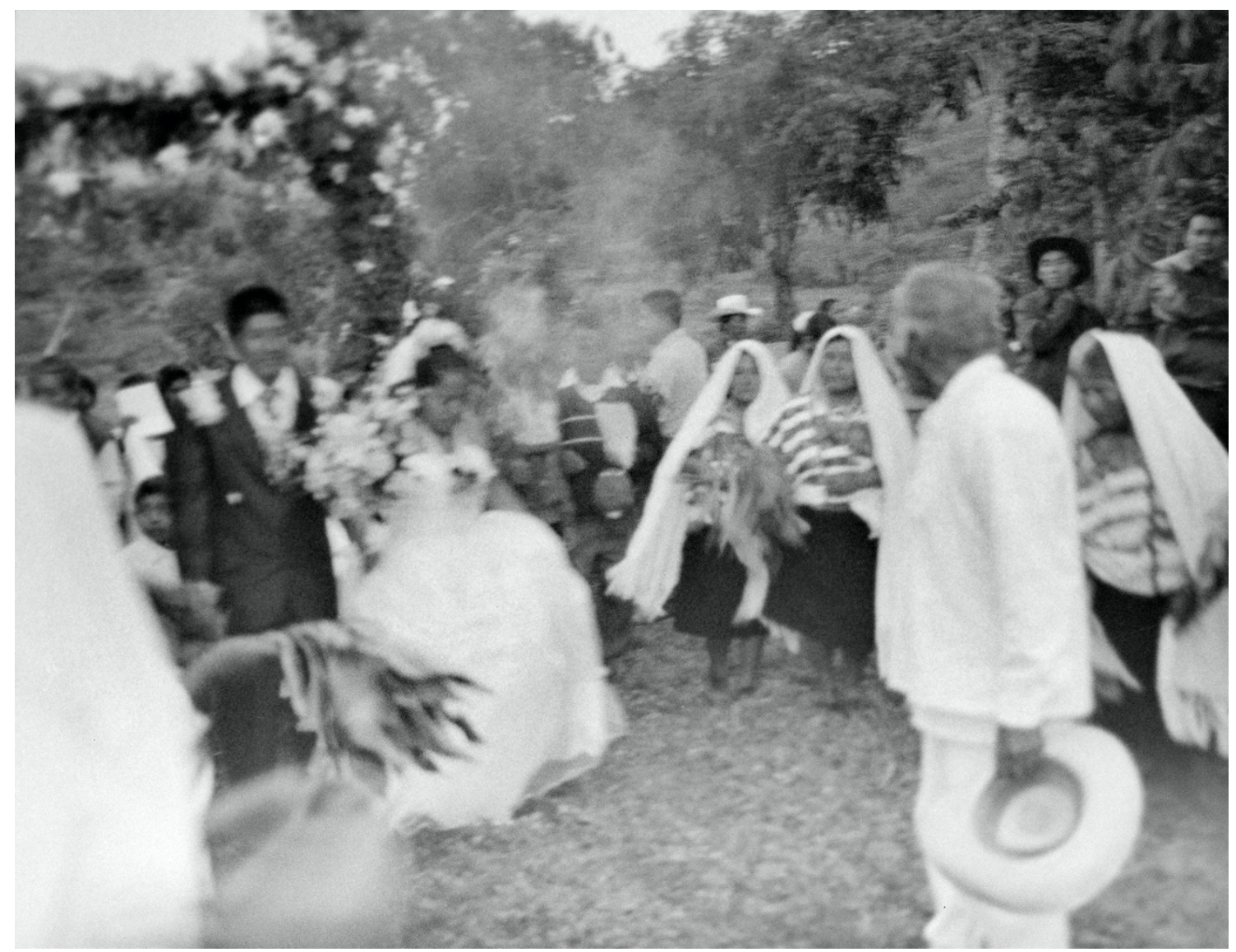

Foto 22

Ao chegarem, os noivos atravessam um portal enfeitado com folhas e flores. São recebidos pelo Embaixador e pelas madrinhas que movimentam as suas ervas sagradas aos ventos, pronunciando palavras de benção e vida harmoniosa ao casal e sua nova família Durante seu trajeto em direção ao espaço principal a onde será realizada a festa, eles são defumados com nopal (foto 23), para afastar todos os maus espíritos e aflições da vida no novo casal, assim como criar uma proteção no local da festa.. Concomitante a tudo isso, os músicos convidados para a festa recebem os recebem, formando assim um séquito até o local a onde será realizada a festa (foto 24 ). 


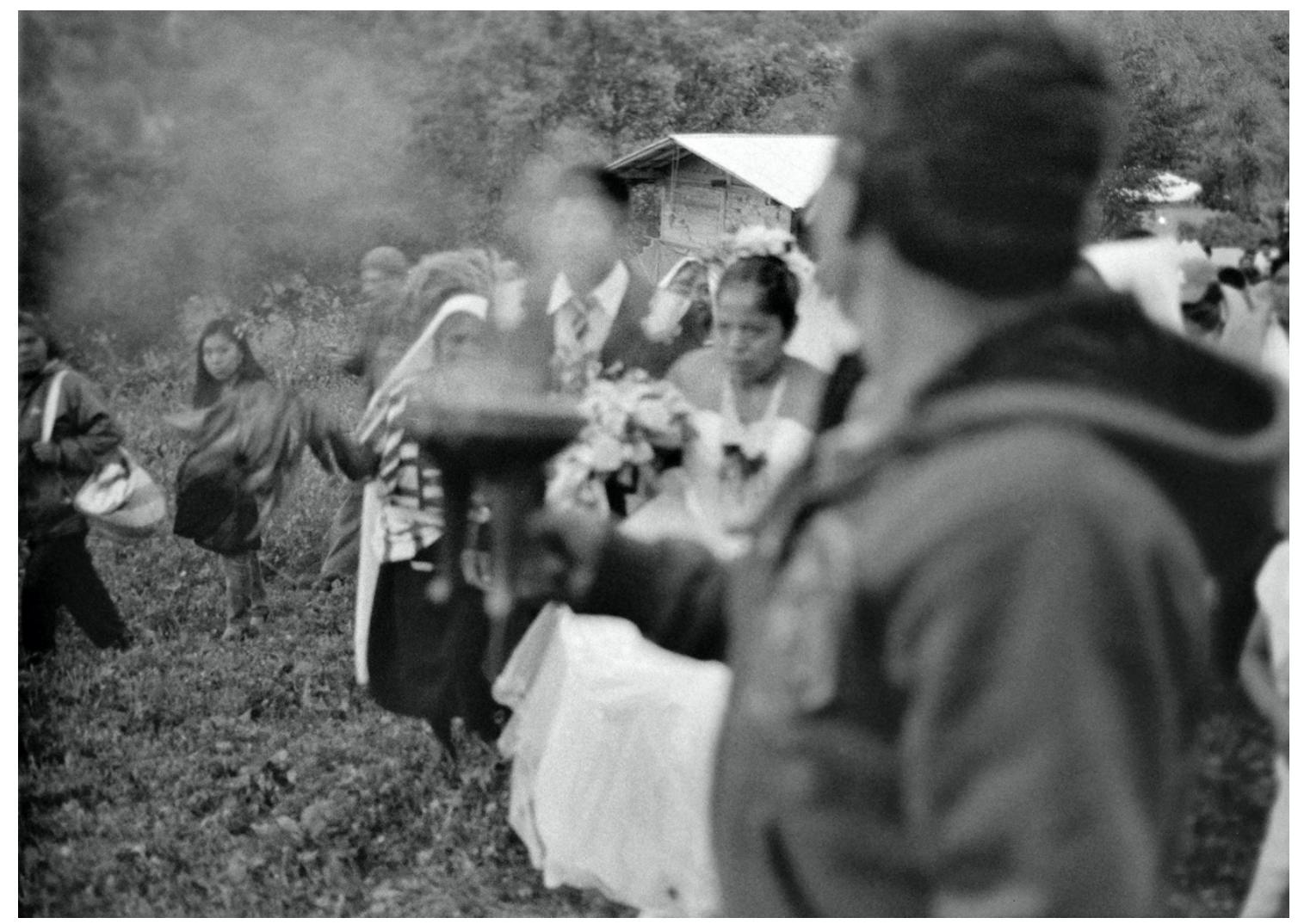

Foto 23

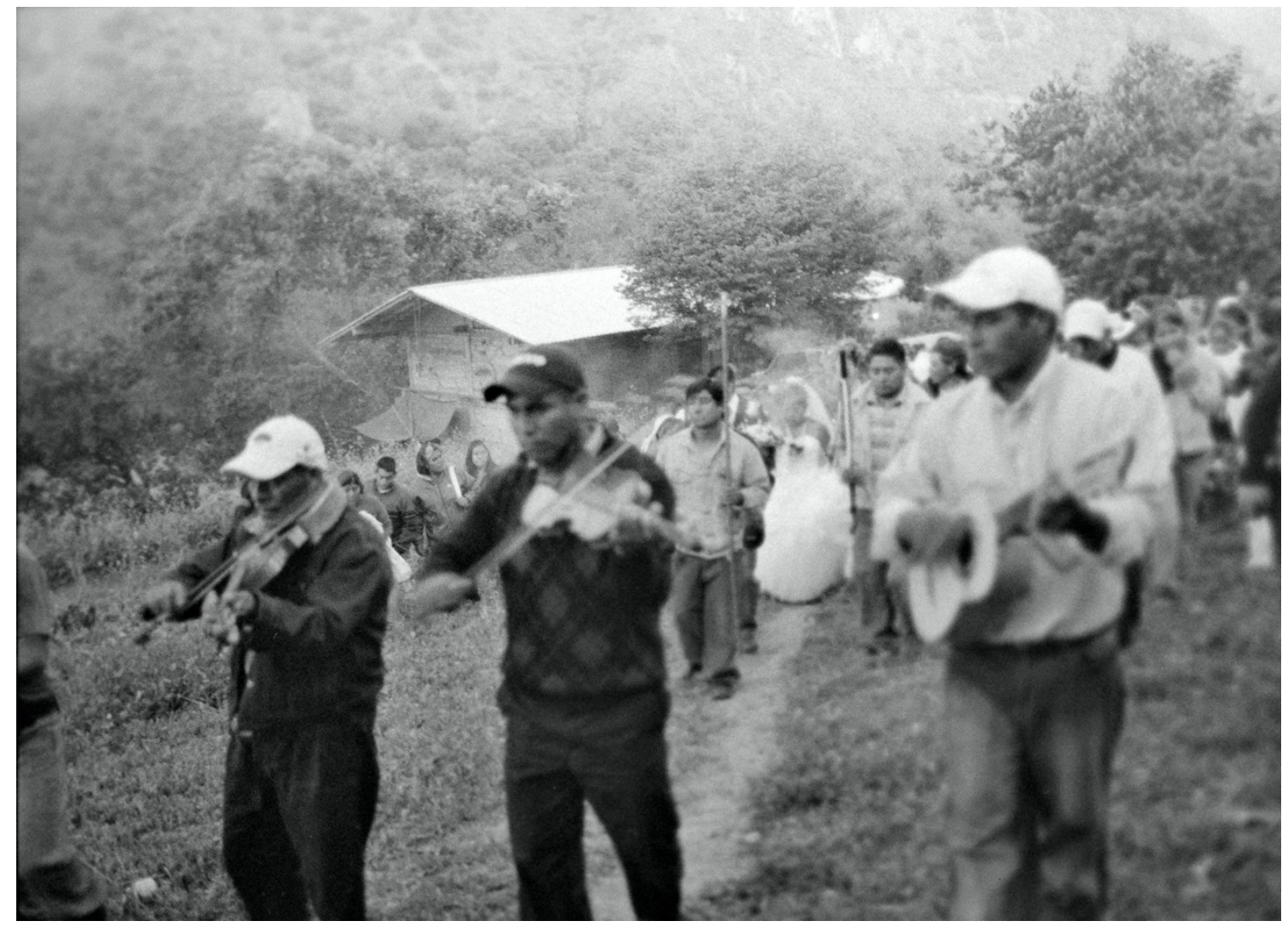

Foto 24 
Finalmente, o casal chega no espaço destinado a festa. Todos os convidados vão chegando e se assentando no local (foto 25). A festa ainda não irá começar, pois nesse espaço da família de Irineo, novamente o embaixador e o mestre de cerimonias "civil" retomam a palavra. Ficam todos postados diante de uma imagem de quase dois metros de Nossa Senhora de Guadalupe, e ouvem atentos as falas que nesse momento falam do futuro do casal e da força do vinculo que estabeleceram. Novamente a palavra "compromisso" destaca-se em suas falas. Após esse momento solene, tem início a festa, com a distribuição de comidas e bebidas para todos os participantes. Eram mais de duzentas pessoas presentes na festa que se estendeu madrugada adiante. Foram contratados três grupos musicais que tocaram as músicas preferidas das pessoas do lugar: rancheiras e músicas pops.

É importante destacar alguns elementos de todo esse ritual: de um lado o gasto econômico de fazer uma festa para esse número de pessoas (lembrando que na sede da comuna são 173 habitantes), de outro a importância do valor do reconhecimento da linhagem e da família nesses momentos de mobilização de recursos para além do propriamente econômico, mas do valor simbólico e de prestigio dos integrantes da família ali representada. 


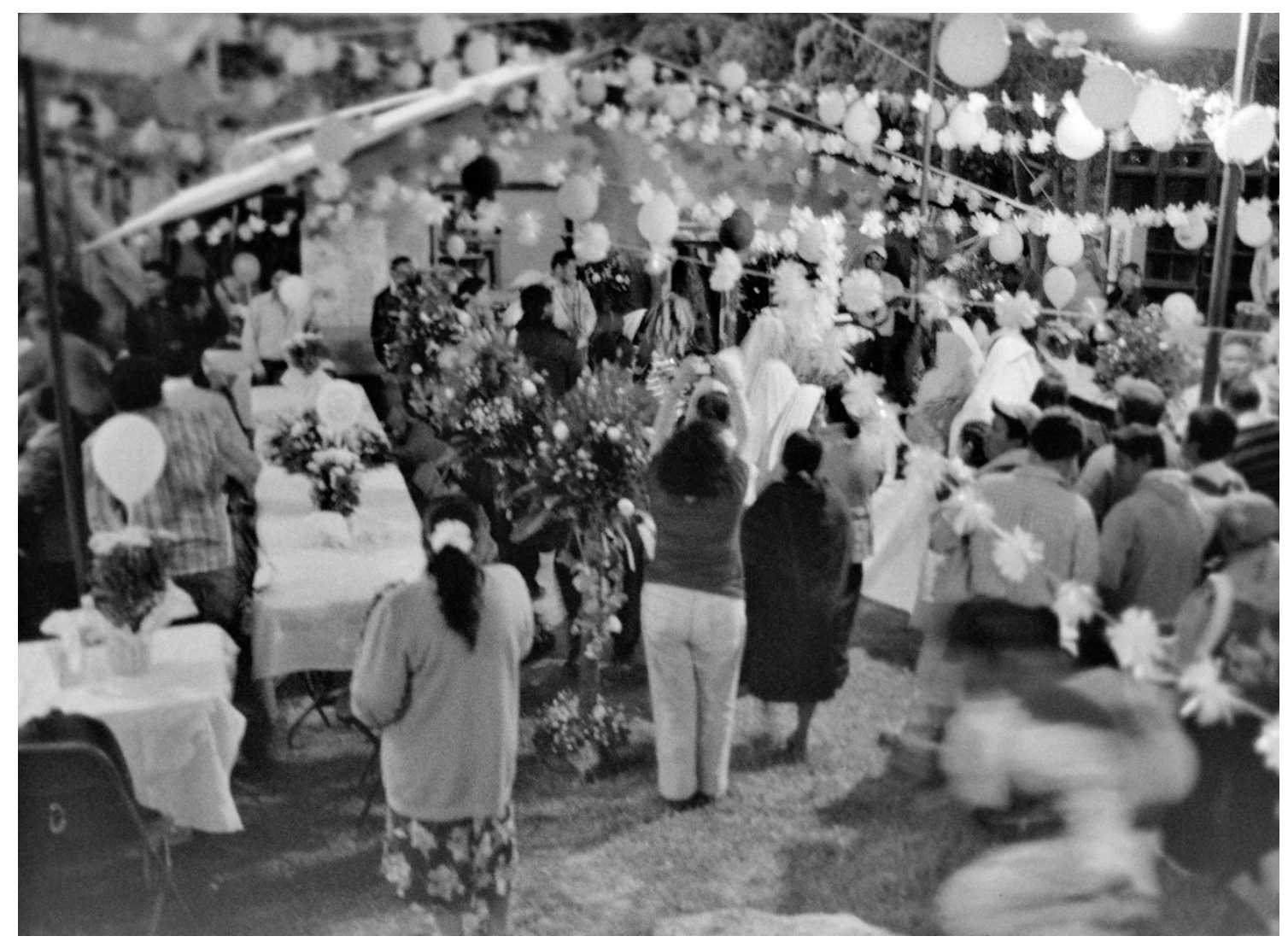

Foto 25

As fotos presentes nesse ensaio são um primeiro esforço de dar conhecimento dessa realidade dos rituais matrimonias nas comunidades indígenas, especialmente mixtecos, no México do século XXI. Não é propriamente uma etnografia visual, embora eu tenha grande familiaridade nesse exercício, creio que está longe de contemplar todos os elementos que são requeridos para uma etnografia propriamente dita. No entanto, pude observar que não temos muitos trabalhos com imagens sobre esse tema. Quando realizo uma pesquisa básica sobre os rituais de matrimonio mixteco, sou levada aos códices que os retratam. Imagino que exista uma bibliografia especifica sobre o tema que no entanto, não consegui aceder. De toda forma, gostaria de finalizar com duas questões: a primeira que ao dar visibilidade a esse material creio ser possível estimular outras pesquisas sobre o tema, já que nele pude observar que há uma dimensão mais privada digamos assim, da família/linhagem e outra mais pública. Outro elemento que tem marcado meus trabalhos nesse campo é o de me colocar de forma mais direta na condição de efetivamente um estranho "emico" ao olhar sobre aquela realidade por mim observada. Nesse sentido, crio que o uso de fotos em preto e branco, tem sido para mim, um marco importante de diferença da minha posição face ao que observo. Nesse 
sentido, meus novos amigos e amigas mexicanas fizeram também as suas fotos coloridas em máquinas digitais.

Para concluir - como algo também que tem marcado minha dimensão de pesquisa com imagens - entregamos para Rosalba e Irineo no final de agosto daquele mesmo ano, o esperado álbum de fotografias do casamento, já que éramos os padrinhos e madrinhas das fotos. Eles receberam de nossa parte, dois álbuns - um com as fotos em p\&b e outro com as fotos coloridas feitas por Ana e Vladhimir. Foi um momento muito emocionante, porque todo o vivido no dia de suas bodas foi de alguma forma eternizado - como instantâneos da felicidade.

\section{REFERENCIA}

Robichaux, D. (ed.) El Matrimonio em Mesoamérica ayer y hoy: unas miradas antropológicas, CMX :Universidade Ibero-Americana, 2003.

Recebido: $01 / 06 / 2020$

Aprovado: 04/09/2020 